\title{
Investigation of water quality changes in drinking water supplied from Sitlee water treatment plant on River Tawi to Old Jammu city, Jammu, J\&K, India
}

\section{Poonam Kundan}

Department of Environmental Sciences, University of Jammu, Jammu-180006, J\&K, India Deepika Slathia*

Department of Environmental Sciences, University of Jammu, Jammu-180006, J\&K, India

${ }^{*}$ Corresponding author. E-mail: dsenviron2012@gmail.com

\begin{abstract}
In the present study, an attempt has been made to evaluate the water quality changes in River Tawi water treated at Sitlee water treatment plant, and supplied for drinking to Old Jammu City, Jammu, J\&K, India. Water samples from the treated water unit of Sitlee water treatment plant and around ten houses from the distribution point (Old Jammu City) were analyzed monthly for various physicochemical parameters for a period of one year (February 2014 to January 2015). The study indicated deterioration of drinking water quality during its passage through the distribution network which has been attributed to the leakages and defects in the old pipe system supplying water to the Jammu city. Comparison of analyzed water quality parameters with the drinking water standards prescribed by World Health Organization (WHO) and Bureau of Indian Standards (BIS) indicated that parameters like DO $(7.49-8.24 \mathrm{mg} / \mathrm{l})$, calcium(49.93-67.08mg/l), magnesium $(16.14-25.21 \mathrm{mg} / \mathrm{l})$ and potassium(6.99-7.93mg/l) were almost nearing the desirable limits but were within the permissible limits and parameters like turbidity(3.5-8.17 NTU) and total hardness $(78.87-120.50 \mathrm{mg} / \mathrm{l})$ were above the desirable limits in the water samples collected from the distribution point. The collected primary data for the thirteen water quality parameters has been used to calculate the Arithmetic Water Quality Index(WQI) which has shown monsoon increase with higher values at distribution point(65.65). One time microbial analysis (MPN/100ml) for total and faecal coliform has indicated presence of faecal coliform $(<1 / 100 \mathrm{ml})$ in water samples from eight households at distribution point which indicates contamination of water with human faecal matter during its passage through the distribution network. According to microbial standards laid down by Central Pollution Control Board (2008), water contaminated with faecal coliform is unfit for drinking without conventional treatment.
\end{abstract}

Keywords: Distribution network, Raw water, River Tawi, Sitlee water treatment plant, treated water, Water Quality Index

\section{INTRODUCTION}

Water is the fundamental need of human beings to sustain life. Safe drinking water supports public health and ensures economic growth whereas, contaminated water causes social and economic damages through water-related diseases such as cholera, dysentery, typhoid fever, hepatitis A, poliomyelitis, E. coli. infections and thus, increases medical treatment costs (Rossi et al. 2012). According to Wankhade (2015), nearly 62 percent of the total 70 per cent households having access to tap water in Indian cities, have access to treated tap water and only 49 per cent households have access to piped water supply within their premises. To provide ample and assured supply of quality water, a number of water treatment plants have come up in the country which lift raw water from

\section{Article Info}

DOI:10.31018/jans.v10i2.1742 Received: November 10, 2017

Revised: March 20, 2018

Accepted: April 7, 2018

\section{How to Cite}

Kundan, P. and Slathia, D. (2018).Investigation of water quality changes in drinking water supplied from Sitlee water treatment plant on River Tawi to Old Jammu city, Jammu, J\&K, India. Journal of Applied and Natural Science, 10(2): $601-607$ rivers, dams etc., treat it through various treatment processes and supply the treated water to the public or communities on daily basis. The purpose of water treatment plant is production of water that is safe for human consumption, appealing to the consumer, non-corrosive and non-scaling, and can be constructed and operated at a reasonable cost (Edzwald, 2011). But most of the piped water supply systems in various Indian cities are rarely able to meet the drinking water standards laid down in the Manual on Water Supply and Treatment (CPHEEO, 1999). Water treatment involves physical, chemical and biological changes that transform raw water into potable water and selection of treatment process is of great importance for achieving high contaminant removal efficiency (Mirsepassi, 2004; Yan et. al., 2007). Also, water distribution systems play a pivotal role in preserv- 
ing and providing quality water to the public. Drinking water quality usually deteriorates during collection and storage (Trevett et al., 2005) as well as in distribution networks (Lehtola et al., 2005; Karavoltsos et al., 2008). Therefore, it becomes imperative to monitor water quality at each stage of treatment. Surveillance of drinking water quality (SDWQ) is the continuous and vigilant public health assessment and overview of the safety and acceptability of drinking water supplies (WHO, 2004). SDWQ is instituted to minimize the incidence of chemical and biological toxicity and to boost consumer confidence in the water they use (Leeuwen, 2000). Most of the studies have documented that quality of treated water, when released into the distribution system gets altered during its passages through pipes, stand pipes and storage tanks. There is extensive literature indicating poor water quality in terms of some physicochemical parameters even after treatment of raw water at treatment plants (Shareef et al. 2009 reported turbidity above permissible levels in water treated at one of three water treatment plants on River Zab, Iraq; Hamza, 2012 concluded that treated water quality of Tigris river water was not good for public consumption at three treatment plants viz. Sharq Diglla, Al-Qadisiaand AlKarama, Baghdad, Iraq) or its quality deterioration in terms of physicochemical and microbial characteristics while passing through the distribution system (Sorlini et al. 2013 observed high turbidity values in piped water supplied to Chad-Camerron, Fadaei and Sadeghi, 2014 noticed treated water contaminated with coliform bacteria in the distribution system in Shahrekord, Iran.) and from supply to consumer either during collection and storage (Trevett et al., 2005). Thus, periodical monitoring of drinking water quality of both treated as well as supplied water is mandatory to keep a quality check on the water being supplied to the public so that major outbreaks of various diseases can be prevented. In Jammu city, about 26MGD of surface water is tapped from river Tawi at three treatment plants viz. Sitlee(20MGD), Dhountli(4MGD) and Boria(2MGD) besides supply from various ground water sources(Suthra, 2012).The present study has been undertaken to investigate the changes in drinking water quality right from its treatment at Sitlee treatment plant on River Tawi to its final supply to the ultimate consumer through a network of pipes in the distribution system. The study also suggests various remedial measures to ensure safe distribution of treated water to consumers.

\section{MATERIALS AND METHODS}

Study area: River Tawi, the longest tributary of the River Chenab in Jammu originates from Kali Kund glacier near the Kaplas Mountain, Bhadarwah in the Doda district and is 141 kilome- ters long from its source till Indian border, where it enters into Sialkote district of Pakistan and joins the river Chenab. It is an important water source to the inhabitants all along its length. Sitlee water treatment complex is located on River Tawi near Nagrota bye pass in Sitlee and was commissioned in 1986. Raw water from the River Tawi is lifted through pumps and collected in three input units. From input units, the water is made to pass through the sedimentation tanks where mud and other particles settle down. From sedimentation tanks, water is allowed to flow through open channels with continuous addition of liquid alum (coagulating agent) and water enters the clariflocculator tank. The clear water from the clariflocculation unit enters the outer drains and is fed to the filtration tanks where the water is pushed through the sand-gravel bed to sieve the impurities, inorganic and organic, including biological ones. The filtered water is made to pass through the chlorination channel, where liquid bleaching powder is added in order to eliminate biologically harmful microbes. Finally the treated water is supplied to Central Pumping station from where it is supplied to three regions of Jammu City; Old Jam$\mathrm{mu}$, Janipura region and New plot area through network of underground pipes spreading all over Jammu city(Fig 1).

Methodology: For the present study, water samples were collected on monthly basis from the treated site of Sitlee water treatment unit and ten households of Old Jammu city (distribution point) for a period of twelve months from February 2014 to January 2015(Fig.2). The samples were collected in polypropylene plastic bottles of 2 litre capacity and analyzed in laboratory within four hours of their collection using standard techniques (APHA, 2005). The types of analysis varied from simple field testing for a single analyte to laboratory based multi-component instrumental analysis. In the present paper, mean of following months was taken to represent seasonal variations viz. Summer (March-June), Monsoon (July-October) and Winter (November- February). For bacteriological

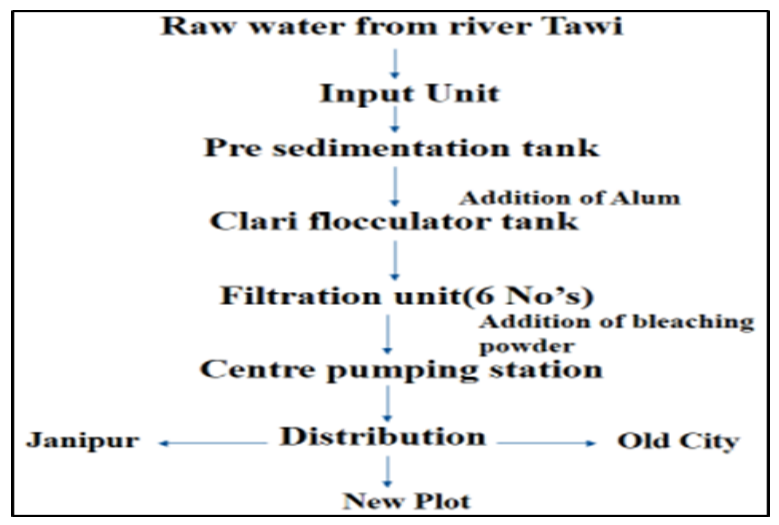

Fig.1. Showing treatment process followed at Sitlee water treatment plant before water distribution. 
analysis, water samples were collected from various sites only once during monsoon in sterilized wide mouth BOD bottles by plunging its neck downward below the surface that was later tilted upwards. The bottles were sealed and brought to lab for analysis. Microbial analysis of water was done using Multiple tube technique (APHA,2005). MPN/100ml was calculated for both total and faecal coliforms. In order to determine the variations in drinking water quality, arithmetic water quality index(WQI) was calculated using thirteen water quality parameters $(\mathrm{pH}$, turbidity, TDS, total alkalinity, chloride, calcium, magnesium, total hardness, DO, BOD, sodium, potassium and nitrate) using the formula as given by Brown et al. (1972):

$$
\text { WQI }=\sum_{n=1}^{12}\left(q_{n}, W_{n}\right) / \sum_{n=1}^{12}\left(w_{n}\right)
$$

Where,

$\mathrm{n}=$ number of variables

$w_{n}$ is the relative weight of the $n^{\text {th }}$ parameter $\left(w_{n}\right.$ of various water quality parameters is inversely proportional to the recommended standard for the corresponding parameter)

$\mathrm{q}_{\mathrm{n}}$ is the water quality rating of $\mathrm{n}^{\text {th }}$ parameter

Computed water quality index values were categorized using water suitability classification given by Brown et al. (1972).

\section{RESULTS AND DISCUSSION}

The analytical results of seasonal variations in the physicochemical parameters of the treated water from Sitlee water treatment plant and old city distribution point, Jammu have been tabulated in
Table 1 . The findings have clearly indicated that the drinking water quality is strongly influenced by various anthropogenic factors while it moves through the distribution system. In the present study, water temperature closely followed atmospheric temperature and observed summer increase and winter decline at both the sites. Electrical conductivity and total dissolved solids observed a direct relationship and both increased during monsoon $(228.50 \mu \mathrm{S} / \mathrm{cm}$ and $117.08 \mathrm{ppm}$ at treated site; $249 \mu \mathrm{S} / \mathrm{cm}$ and 158ppm at distribution point) with winter decline $(138.50 \mu \mathrm{S} / \mathrm{cm}$ and $85.30 \mathrm{ppm}$ at treated site; $139.50 \mu \mathrm{S} / \mathrm{cm}$ and $86.86 \mathrm{ppm}$ at distribution point). Direct relationship between EC and TDS is already on record (Wetzel, 2001). Turbidity also followed the similar seasonal trend as that of EC and TDS and observed monsoon increase. Monsoon increase in all these parameters may be attributed to overflowing drains due to increased runoff resulting in the entry of sewage and salts along with sediments through defective crosssections of pipes passing through these drains in the distribution system (Fig.3a-c). Defective joints and leaking pipes in the distribution were noticed during the present study. According to Hamza (2012), there is release of inorganic sediments generally trapped by biofilms formed by microbial decomposition of waste due to high pressure during water distribution inside the pipes. $\mathrm{pH}$ reduction from treated site(6.8-7.43) to distribution point (6.50-7.14) may be due to nitrification of the sewage entering the distribution system from leaking pipes passing through the drains (Langmuir et al.,

Table1. Seasonal variations in physicochemical characteristics of water samples from treated site and the distribution point(Old Jammu City).

\begin{tabular}{|c|c|c|c|c|c|c|c|}
\hline \multirow{2}{*}{$\begin{array}{l}\text { Samples } \\
\text { ParametersIMonths }\end{array}$} & \multicolumn{3}{|c|}{ Treated Water } & \multicolumn{4}{|c|}{ Distribution water } \\
\hline & Units & Summer & Monsoon & Winter & Summer & Monsoon & Winter \\
\hline Air temp. & ${ }^{\circ} \mathrm{C}$ & 29 & 26.88 & 16.88 & 27.75 & 27.00 & 16.25 \\
\hline Water temp. & ${ }^{\circ} \mathrm{C}$ & 24.88 & 27.50 & 15.25 & 24.42 & 26.75 & 16.04 \\
\hline $\mathrm{pH}$ & & 6.93 & 6.81 & 7.43 & 6.50 & 6.83 & 7.14 \\
\hline EC & $\mu S / \mathrm{cm}$ & 212.50 & 228.50 & 138.50 & 216.83 & 249.00 & 139.50 \\
\hline TDS & $\mathrm{mg} / \mathrm{l}$ & 105.70 & 117.08 & 85.30 & 105.48 & 158.71 & 86.86 \\
\hline Turbidity & NTU & 2.25 & 5.25 & 3.25 & 3.5 & 8.17 & 4.58 \\
\hline DO & $\mathrm{mg} / \mathrm{l}$ & 7.44 & 7.40 & 8.59 & 7.80 & 7.49 & 8.24 \\
\hline BOD & $\mathrm{mg} / \mathrm{l}$ & 0.78 & 0.77 & 0.38 & 0.69 & 0.86 & 0.23 \\
\hline Free $\mathrm{CO}_{2}$ & $\mathrm{mg} / \mathrm{l}$ & 8.35 & 9.82 & 8.46 & 11.06 & 10.18 & 9.54 \\
\hline Total alkalinityCaCO${ }_{3}$ & $\mathrm{mg} / \mathrm{l}$ & 110.74 & 109.07 & 75.15 & 118.58 & 108.06 & 81.80 \\
\hline $\mathrm{Cl}^{-}$ & $\mathrm{mg} / \mathrm{l}$ & 12.33 & 13.30 & 9.28 & 12.44 & 15.97 & 9.39 \\
\hline $\mathrm{Ca}^{2+}$ & $\mathrm{mg} / \mathrm{l}$ & 49.21 & 58.60 & 62.88 & 49.93 & 54.82 & 67.08 \\
\hline $\mathrm{Mg}^{2+}$ & $\mathrm{mg} / \mathrm{l}$ & 11.58 & 12.48 & 13.72 & 16.14 & 17.76 & 25.21 \\
\hline $\mathrm{TH}$ & $\mathrm{mg} / \mathrm{l}$ & 59.91 & 65.96 & 72.16 & 78.87 & 86.08 & 120.50 \\
\hline $\mathrm{NO}_{3}^{-}$ & $\mathrm{mg} / \mathrm{l}$ & 0.12 & 0.24 & 0.16 & 0.12 & 0.35 & 0.17 \\
\hline $\mathrm{PO}_{4}{ }^{3-}$ & $\mathrm{mg} / \mathrm{l}$ & 0.15 & 0.17 & 0.07 & 0.15 & 0.18 & 0.09 \\
\hline $\mathrm{SO}_{4}^{2-}$ & $\mathrm{mg} / \mathrm{l}$ & 4.65 & 5.93 & 1.70 & 5.07 & 6.30 & 2.05 \\
\hline Silicates & $\mathrm{mg} / \mathrm{l}$ & 11.78 & 15.88 & 9.35 & 11.32 & 18.10 & 9.46 \\
\hline $\mathrm{Na}^{+}$ & $\mathrm{mg} / \mathrm{l}$ & 8.55 & 15.05 & 16.73 & 11.13 & 13.58 & 16.35 \\
\hline $\mathrm{K}^{+}$ & $\mathrm{mg} / \mathrm{l}$ & 7.93 & 8.03 & 6.98 & 7.77 & 7.93 & 6.99 \\
\hline $\begin{array}{l}\text { MPN/100ml(Total Coli- } \\
\text { form) }\end{array}$ & & - & 0 & - & - & $<1$ & - \\
\hline $\begin{array}{l}\text { MPN/100ml(Faecal Coli- } \\
\text { form) }\end{array}$ & & - & 0 & - & - & $<1$ & - \\
\hline
\end{tabular}


Kundan P. and Slathia D. / J. Appl. \& Nat. Sci. 10 (2): 601 - 607 (2018)

Table 2. Comparison of water quality parameters (treated water \&distribution point) with WHO and BIS drinking water quality standard.

\begin{tabular}{|c|c|c|c|c|c|c|c|c|c|}
\hline \multirow[b]{2}{*}{$\begin{array}{l}\text { Parame- } \\
\text { ters }\end{array}$} & \multirow[t]{2}{*}{ Units } & \multicolumn{2}{|c|}{ Treated water } & \multicolumn{2}{|c|}{ Distribution point } & \multicolumn{2}{|c|}{ WHO (2008) } & \multicolumn{2}{|c|}{ BIS (1991) } \\
\hline & & Min. & Max. & Min. & Max. & $\begin{array}{l}\text { Desir- } \\
\text { able }\end{array}$ & Permissible & $\begin{array}{l}\text { Desira- } \\
\text { ble }\end{array}$ & Permissible \\
\hline Air temp & ${ }^{\circ} \mathrm{C}$ & 16.88 & 29 & 16.25 & 27.75 & & & & \\
\hline W. Temp & ${ }^{\circ} \mathrm{C}$ & 15.25 & 27.50 & 16.04 & 26.75 & & & & \\
\hline $\begin{array}{l}\mathrm{pH} \\
\mathrm{EC}\end{array}$ & $\mu S / \mathrm{cm}$ & $\begin{array}{l}6.8 \\
138.50\end{array}$ & $\begin{array}{l}7.43 \\
250.5\end{array}$ & $\begin{array}{l}6.50 \\
139.50\end{array}$ & $\begin{array}{l}7.14 \\
249\end{array}$ & $6.5-8.5$ & $\begin{array}{l}\text { No relaxation } \\
1500\end{array}$ & $6.5-8.5$ & $\begin{array}{l}\text { No relaxation } \\
3000\end{array}$ \\
\hline $\begin{array}{l}\text { TDS } \\
\text { Turbidity } \\
\text { DO }\end{array}$ & $\begin{array}{l}\mathrm{mg} / \mathrm{l} \\
\mathrm{NTU} \\
\mathrm{mg} / \mathrm{l}\end{array}$ & $\begin{array}{l}85.30 \\
3.25 \\
8.4\end{array}$ & $\begin{array}{l}117.08 \\
5.25 \\
10.24\end{array}$ & $\begin{array}{l}86.86 \\
4.58 \\
8.49\end{array}$ & $\begin{array}{l}118.17 \\
8.17 \\
9.59\end{array}$ & $\begin{array}{l}600 \\
5\end{array}$ & $\begin{array}{l}1000 \\
10 \\
5-7^{* *}\end{array}$ & $\begin{array}{l}500 \\
5\end{array}$ & $\begin{array}{l}2000 \\
10\end{array}$ \\
\hline BOD & $\mathrm{mg} / \mathrm{l}$ & 0.38 & 0.87 & 0.23 & 0.86 & & & & \\
\hline $\begin{array}{l}\mathrm{Cl}^{-} \\
\mathrm{FCO}_{2}\end{array}$ & $\begin{array}{l}\mathrm{mg} / \mathrm{l} \\
\mathrm{mg} / \mathrm{l}\end{array}$ & $\begin{array}{l}9.28 \\
8.35\end{array}$ & $\begin{array}{l}13.30 \\
9.82\end{array}$ & $\begin{array}{l}9.39 \\
9.54\end{array}$ & $\begin{array}{l}13.47 \\
11.06\end{array}$ & 250 & 600 & 250 & 1000 \\
\hline TA & $\mathrm{mg} / \mathrm{l}$ & 75.15 & 110.74 & 81.80 & 118.58 & & & 200 & 600 \\
\hline $\begin{array}{l}\mathrm{Ca}^{2+} \\
\mathrm{Mg}^{2+} \\
\mathrm{TH} \\
\mathrm{NO}_{3}^{-}\end{array}$ & $\begin{array}{l}\mathrm{mg} / \mathrm{l} \\
\mathrm{mg} / \mathrm{l} \\
\mathrm{mg} / \mathrm{l} \\
\mathrm{mg} / \mathrm{l}\end{array}$ & $\begin{array}{l}49.21 \\
11.58 \\
29.91 \\
0.12\end{array}$ & $\begin{array}{l}62.88 \\
13.72 \\
72.16 \\
0.24\end{array}$ & $\begin{array}{l}49.93 \\
16.14 \\
78.87 \\
0.12\end{array}$ & $\begin{array}{l}67.08 \\
25.21 \\
120.50 \\
0.35\end{array}$ & $\begin{array}{l}100 \\
30^{*} \\
100 \\
50\end{array}$ & $\begin{array}{l}300 \\
150^{*} \\
500\end{array}$ & $\begin{array}{l}75 \\
30 \\
300 \\
45\end{array}$ & $\begin{array}{l}200 \\
100 \\
600 \\
100\end{array}$ \\
\hline $\mathrm{PO}_{4}{ }^{2-}$ & $\mathrm{mg} / \mathrm{l}$ & 0.07 & 0.17 & 0.09 & 0.18 & & & & \\
\hline $\begin{array}{l}\mathrm{SO}_{4}{ }^{2-} \\
\mathrm{SiO}_{3}{ }^{2-}\end{array}$ & $\begin{array}{l}\mathrm{mg} / \mathrm{l} \\
\mathrm{mg} / \mathrm{l}\end{array}$ & $\begin{array}{l}1.70 \\
9.35\end{array}$ & $\begin{array}{l}5.93 \\
15.88\end{array}$ & $\begin{array}{l}2.05 \\
9.46\end{array}$ & $\begin{array}{l}6.30 \\
18.10\end{array}$ & 250 & 400 & 250 & 400 \\
\hline $\mathrm{Na}^{+}$ & $\mathrm{mg} / \mathrm{l}$ & 8.55 & 16.73 & 11.13 & 16.35 & 50 & 200 & & \\
\hline $\mathrm{K}^{+}$ & $\mathrm{mg} / \mathrm{l}$ & 6.98 & 8.03 & 6.99 & 7.93 & $10^{*}$ & $12^{*}$ & & \\
\hline
\end{tabular}

*Standards prescribed by WHO (1997), ${ }^{* *}$ Standards prescribed by WHO (1993)

2005). $\mathrm{pH}$ decline may also be due to corresponding increase in free $\mathrm{CO}_{2}$ at the distribution points. An inverse relationship between $\mathrm{pH}$ and free $\mathrm{CO}_{2}$ is already on record (Hutchinson, 2004).Dissolved oxygen observed variation between $7.40 \mathrm{mg} / \mathrm{l}$ (monsoon) to $8.29 \mathrm{mg} / \mathrm{l}$ (winter) at treated site and $7.49 \mathrm{mg} / \mathrm{l}$ (monsoon) to $8.24 \mathrm{mg} / \mathrm{l}$ (winter) at distribution point. Seasonally, dissolved oxygen showed high values during winter with decline during monsoon. Reduced microbial activity and decline in free $\mathrm{CO}_{2}$ concentration which increases $\mathrm{DO}$ solubility may explain winter rise in dissolved oxygen (Joshi et al., 2009). BOD showed inverse relationship with DO and showed higher concentration at distribution point $(0.23-0.86 \mathrm{mg} / \mathrm{l})$ as compared to treated site $(0.38-0.77 \mathrm{mg} / \mathrm{l})$. Slight increase in BOD concentration at distribution points may be due to growth of biofilms at leaking and breakage points of water pipes and microbial decomposition of sewage and dead organic matter entering through suction from the leaking pipes in the distribution system. The tolerance limit for dissolved oxygen(DO) for inland surface waters(used as raw water and bathing ghat) is $3 \mathrm{mg} / \mathrm{l}$, for sustaining aquatic life is $4 \mathrm{mg} / \mathrm{l}$ whereas for drinking purposes it is $6 \mathrm{mg} / \mathrm{l}($ Weldemariam, 2013). Therefore, the water quality in the present study area comes under the category of fit for domestic use and drinking purposes during most of the seasons. The cationic composition of water observed variations at treated site and distribution point. At treated site, calcium (49.21-62.88 mg/l) showed dominance followed by sodium(8.55-15.05mg/l), magnesium(11.58-13.72mg/l) and potassium(6.98$8.03 \mathrm{mg} / \mathrm{l}$. However, at distribution point, calcium (49.93-67.09mg/l) was observed as dominant cation followed by magnesium(16.14-25.21 mg/l), sodium $(11.13-16.35 \mathrm{mg} / \mathrm{l})$ and potassium(6.99$7.93 \mathrm{mg} / \mathrm{l})$. Calcium, magnesium and total hardness observed increase at distribution point with almost similar seasonal pattern of increase and decrease. Water from treated site and distribution point remained moderately hard throughout the year (TH: 59.91-72.16; 78.87-120.50 mg/l) with slight increase towards hard water at distribution point. Anionic spectrum of the water samples from treated site and distribution point recorded similar composition with bicarbonate as dominant anion (75.15-110.74mg/l;81.80-118.58mg/l) followed by silicate $(9.35-15.88 \mathrm{mg} / \mathrm{l} ; 9.46-18.10 \mathrm{mg} / \mathrm{l}), \quad$ chloride (9.28-13.30mg//;9.39-15.97mg/l), sulphate(1.70$5.93 \mathrm{mg} / 2.05-6.30 \mathrm{mg} / \mathrm{l})$, nitrate $(0.12-0.24 \mathrm{mg} / \mathrm{l}$; $0.12-0.35)$ and phosphate $(0.07-0.17 \mathrm{mg} / \mathrm{l} ; 0.09$ $0.18 \mathrm{mg} / \mathrm{l})$. Among various anions, increase in chloride concentration in the distribution system may be due to rechlorination of water at storage tanks in distribution system before the final water supply (WHO, 1997) and pollution from chloride 
Kundan P. and Slathia D. / J. Appl. \& Nat. Sci. 10 (2): 601 - 607 (2018)

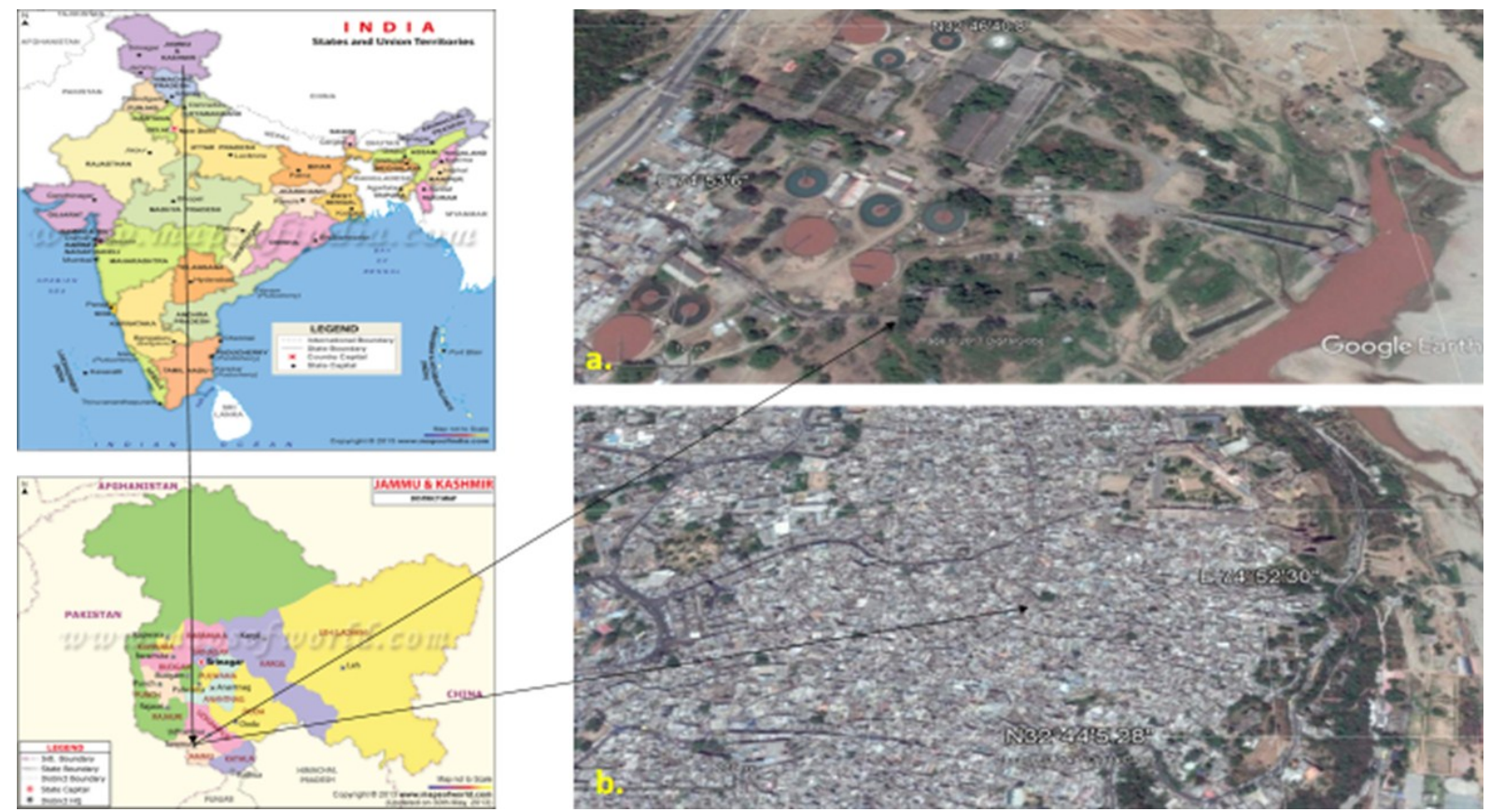

Fig.2. Showing location of J\&K a. Sitlee water treatment site b. the water distribution site (Old Jammu city).

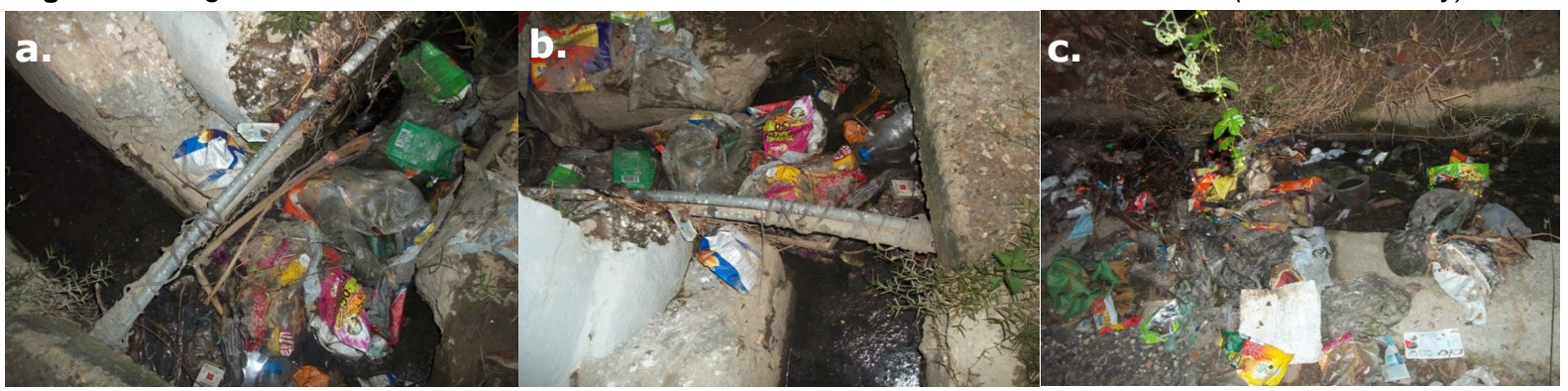

Fig. 3 (a-c). Water supply pipes passing through drains at the old Jammu distribution point.

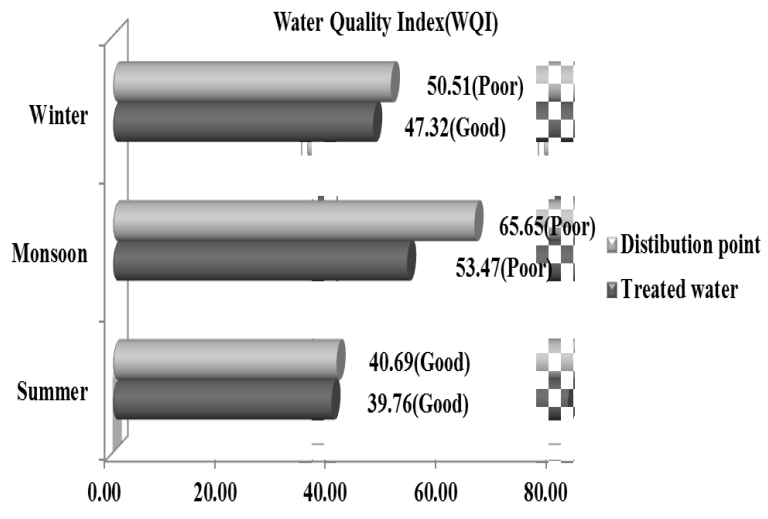

Fig. 4. Seasonal variation of Water Quality Index (WQI) and its categorization at the two sites.

rich effluent of sewage and municipal waste during cross contamination of pipes (Geldreich, 1996; Zakari et al., 2014). High amount of chloride as indicative of pollution load of human and animal origin in a water body is already on record (Singh et al., 2010, 2014; Slathia and Dutta, 2013). Cationic and anionic concentration in the present study has observed monsoon increase with higher records at distribution point than the treated water site and may be attributed to microbial decomposition of dead organic matter entering into the pipes during crossing of pipes through drains due to back siphonage, cracks, defective joints etc. However, cationic dominance of calcium and anionic dominance of bicarbonate in both treated as well as distributed water is similar to their dominance in other freshwater streams and rivers of the area.

Microbial analysis (MPN/100 ml) for total coliforms and faecal coliforms: Most probable number (MPN/100ml) for total coliforms and faecal coliforms was observed to be $0 / 100 \mathrm{ml}$ in treated water and $<1 / 100 \mathrm{ml}$ in distribution point during monsoon (Table 1). According to CPCB (2008), the total Coliform level should not exceed 50 MPN/100ml to recommend the water as potable without conventional treatment but after disinfection under the Class $A$ of drinking water. However, MPN/100ml for faecal coliform should be zero for drinking water. Thus, the present microbial quality study of distribution system has indicated that distribution water is unfit for drinking without conventional treatment. 
Comparison with national and international standards: Comparison of seasonal variations of various physicochemical characteristics of water from treated site and distribution point with various National and International standards reveals that most of the parameters are within permissible limits for drinking water as prescribed BIS(1991) and $\mathrm{WHO}(2008)$ standards except turbidity and total hardness which are high as compared to the desirable limits. However, most of the parameters are observed to be marginal for drinking purposes and would cross the prescribed limits if proper preventive measures are not taken well in time (Table 2).

Water quality index (WQI): Thirteen water quality parameters were used for the calculation of WQI (Fig. 3). Based on Arithmetic WQI as proposed by Brown et al. (1972), water has been categorized into four categories, viz. Excellent (0-25), Good (26-50), Poor (51-75), Very Poor (76-100) and Unfit for drinking (Above 100). In the present study, WQI has been observed to be maximum during monsoon (poor water quality at both the sites) followed by winter (poor water quality at distribution point and good at treated point) and summer (good water quality at both the sites). WQI for distribution point was observed to be more as compared to the treated water during all the seasons indicating contamination during supply of water from Sitlee water treatment unit to the ultimate consumers. Monsoon and winter high WQI may be ascribed to flooding of drains due to rains resulting in cross contamination of defective/ leaking distribution pipes passing through them.

\section{Conclusion}

Drinking water must be free from components like excess minerals, organic substances and disease causing microorganisms whose presence may adversely affect the human health. The results of the present study indicate that most of the water quality parameters including the cations and anions have shown an increase in the distribution system as compared to the treated water of Sitlee water treatment complex. This clearly indicates contamination of water while moving through the distribution system or during storage in the overhead tanks from the Central pumping station. Comparatively more contamination was observed during monsoon season. It is advisable that authorities should take appropriate steps to check the contamination at the distribution points. Some of the measures which can be taken to reduce contamination and ensure safe and potable supply of water to the consumers include regular monitoring and checking of primary, secondary and tertiary pipes for any leakages and immediate replacement of rusted domestic supply pipes. Location/passing of water pipes through drains should be avoided as it directly or indirectly affects the drinking water quality. The drains should be covered in order to avoid the chances of choking by solid waste and open defecation in the drains should be prohibited.

\section{ACKNOWLEDGEMENTS}

The authors are thankful to Head, Department of Environmental Science, University of Jammu for providing necessary facilities during the present work. Financial assistance provided by University of Jammu is gratefully acknowledged.

\section{REFERENCES}

American Public Health Association(APHA) (2005).American Water Works Association (AWWA) and Water Environment Federation (WEF): Standard methods for the examination of water and waste water, $21^{\text {st }}$ edition, Washington, D.C.

BIS(1991). Indian standard specifications for drinking water IS: 10500-91 (Bureau of Indian Standards) New Delhi, pp. 1-4.

Brown, R.M., McCleiland, N.J., Deininger, R.A. and O'Connor, M.F.(1972).A Water Quality Index - Crossing the Psychological Barrier (Jenkis, S.H., ed.). International Conference on Water Pollution Research, Jerusalem, 6, 787-797.

CPCB (2008). Performance of Sewage treatment plantColiform Reduction, Central Pollution Control Board (CPCB), New Delhi, CUPS/69/2008.

CPHEEO (1999). Manual of water supply and treatment. Central Public Health and Environmental Engineering organization (CPHEEO) Third Edition. Ministry of Urban development, New Delhi

Edzwald, J.K. (2011).Water quality and treatment: a handbook on drinking water. $6^{\text {th }}$ Edition

(American Water Works Association). McGraw-Hill New York.

Fadaei, A. and Sadeghi, M.(2014). Evaluation and assessment of drinking water quality in Shahrekord, Iran. Resources and Environment, 4(3) 168-172.

Geldreich, E. E. (1996). Microbial Quality of Water Supply in Distribution Systems. Lewis Publishers. Boca Raton, FL.

Hamza, J. N. (2012).Impact of Tigris river pollution on the performance of water treatment plants efficiencies in Baghdad city. Iraqi Journal of Chemical and Petroleum Engineering, 9(3) 17-24.

Hutchinson, G.E.(2004).A Treatise on Limnology. Vol. I H.J. Wiley., New York.

Joshi, D. M., Kumar, A. and Agrawal, N.(2009).Studies on physicochemical parameters to assess the water quality of river Ganga for drinking purpose in Haridwar district. Rasayan Journal of Chemistry, 1,195203

Karavoltsos, S., Sakellari, A., Mihopoulos, N., Dassenakis, M., Scoullos, M. (2008). Evaluation of the quality of drinking water in regions of Greece. Desalination, 224: 317-329.

Langmuir, D.(2005). Eh-pH determination. In R.E. Carver, ed. Procedures in Sedimentary Petrology. Wiley-Interscience, New York.

Leeuwen(2000). Safe drinking water: the toxicologist's approach. Food Chem Toxicol., 38 (1Suppl) :S51-8.

Lehtola, M.J., Miettinen,I.T. , Lampola,T., Hirvonen, A. , Vartiainen, T., Pertti J. and Martikainen, P.J.(2005). 
Pipeline materials modify the effectiveness of disinfectants in drinking water distribution systems. Water Research, 39: 1962-1971.

Mirsepassi, A. (2004). Application of Intelligent System for Water Treatment Plant Operation. Iranian Journal of Environmental Health Science And Engineering, 1 (2) $51-57$.

Rossi, E. M., Gerhard, M. I., Zanella, M. S., Bogo, M., Scapin, D. and Oro, D.(2012). Assessment of microbiological quality of water wells in rural properties of the city of West of Santa Catarina, Brazil. Resources and Environment, 2(4) 164-168.

Shareef, K. M., Muhamad, S. G. and Shekhani, N. M. (2009). Physical and chemical status of drinking water from water treatment plants on Greater Zab river. Journal of Applied Sciences and Environmental Management,13(3) 89 - 92.

Singh, J. K., Priyanka., Kumari, P., Prasad, S. and Jha, A. M.(2014). Municipal supply drinking water quality analysis of Samastipur town area, Bihar, India. International Journal of Basic and Applied Science Research, 1(1) 40-47.

Singh, M. R., Gupta, A. and Beeteswari, K. H. (2010).Physicochemical properties of water samples from Manipur river system, India. Journal of Applied Sciences and Environmental Management, 14(4)85-89

Slathia, D. and Dutta, S. P. S.(2013). Hydrobiological Study of a Subtropical Shiwalik Lake, Jammu, J\&K (India). International Journal of Chemical, Environmental \& Biological Sciences, 1(1) 143-149.

Sorlini, S., Palazzini, D., Sieliechi,J.M. and Ngassoum, M.B.(2013). Assessment of physical chemical drinking water quality in the Lagone Valley(ChadCameroon). Sustainability, 5(7): 3060 -3076.

Suthra, V. (2012). City's lifeline turns river of woe. The
Tribune, Online Edition. March $24^{\text {th }} 2012$. Retrieved from http://www.tribuneindia.com/2012/20120324 on 18/07/2017.

Trevett, A.F., Carter, R.C. and Tyrrel, S.F.(2005). The importance of domestic water

quality management in the context of faecal-oral disease transmission. J Water Health, 3 (3) 259-270.

Wankhade, K. (2015). Urban Sanitation in India: Key shifts in the National Policy Frame. Environment \& Urbanization, 27(2): 555-572.

Weldemariam, M.M.(2013). Physico-chemical analysis of Gudbahri river water of Wukro, Eastern Tigrai, Ethiopia, International Journal of Scientific and Research Publications, 3(11) 1-4.

Wetzel, R.G.(2001). Limnology. Lake and River Ecosystems, Third Ed. Academic Press, London.

$\mathrm{WHO}(1993)$. Guidelines for drinking water quality, Second Edition, Volume 1, Recommendations, WHO Geneva.

WHO(1997).Guidelines for drinking water quality. Vol.1 Recommendations, Geneva.

WHO(2004). World Health Report. Geneva, World Health Organization. 1: 1-540.

$\mathrm{WHO}(2008)$. Guidelines for drinking water quality. $3^{\text {rd }} \mathrm{Edn}$. Geneva.

Yan, M., Wang, D., SHI, B., WEI, Q., QU, J. and Tang, H.(2007). Transformations of particles, metal elements and natural organic matter in different water treatment processes, Journal of Environment Science, 271-277.

Zakari, A., Ikudayisi, V. A. and. Giwa, S.(2014). Quality assessment of the changes in the physicochemical parameters in pipe-borne water supplied in Kano metropolis, Nigeria. IOSR Journal of Applied Chemistry, 7(11) 74-81. 